\title{
SOEP
}

SOEPpapers

SOEPDaNoers
on Multidisciplinary Panel Data Research

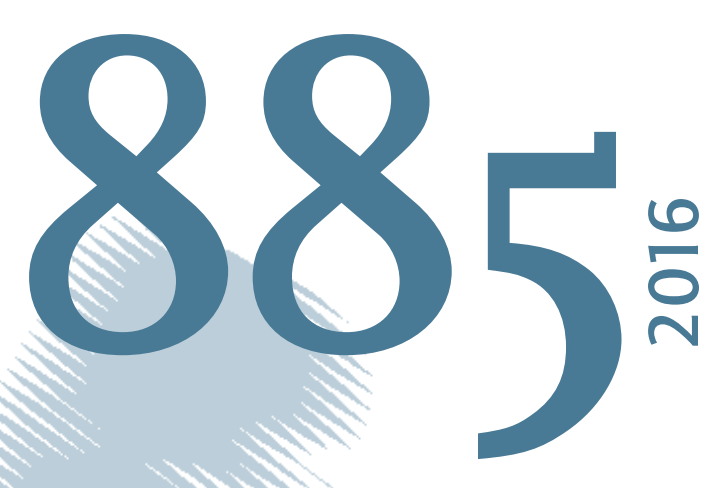

\section{Poverty is a Public Bad: Panel Evidence from Subjective Well-being Data}

Heinz Welsch and Philipp Biermann 
This series presents research findings based either directly on data from the German SocioEconomic Panel study (SOEP) or using SOEP data as part of an internationally comparable data set (e.g. CNEF, ECHP, LIS, LWS, CHER/PACO). SOEP is a truly multidisciplinary household panel study covering a wide range of social and behavioral sciences: economics, sociology, psychology, survey methodology, econometrics and applied statistics, educational science, political science, public health, behavioral genetics, demography, geography, and sport science.

The decision to publish a submission in SOEPpapers is made by a board of editors chosen by the DIW Berlin to represent the wide range of disciplines covered by SOEP. There is no external referee process and papers are either accepted or rejected without revision. Papers appear in this series as works in progress and may also appear elsewhere. They often represent preliminary studies and are circulated to encourage discussion. Citation of such a paper should account for its provisional character. A revised version may be requested from the author directly.

Any opinions expressed in this series are those of the author(s) and not those of DIW Berlin. Research disseminated by DIW Berlin may include views on public policy issues, but the institute itself takes no institutional policy positions.

The SOEPpapers are available at http://www.diw.de/soeppapers

\section{Editors:}

Jan Goebel (Spatial Economics)

Martin Kroh (Political Science, Survey Methodology)

Carsten Schröder (Public Economics)

Jürgen Schupp (Sociology)

Conchita D'Ambrosio (Public Economics, DIW Research Fellow)

Denis Gerstorf (Psychology, DIW Research Director)

Elke Holst (Gender Studies, DIW Research Director)

Frauke Kreuter (Survey Methodology, DIW Research Fellow)

Frieder R. Lang (Psychology, DIW Research Fellow)

Jörg-Peter Schräpler (Survey Methodology, DIW Research Fellow)

Thomas Siedler (Empirical Economics, DIW Research Fellow)

C. Katharina Spieß (Education and Family Economics)

Gert G. Wagner (Social Sciences)

ISSN: 1864-6689 (online)

German Socio-Economic Panel (SOEP)

DIW Berlin

Mohrenstrasse 58

10117 Berlin, Germany

Contact: soeppapers@diw.de

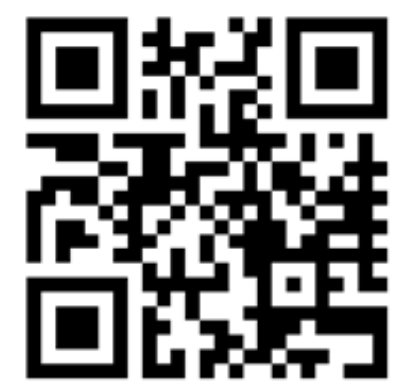




\title{
Poverty is a Public Bad:
}

\section{Panel Evidence from Subjective Well-being Data}

\author{
Heinz Welsch \\ Philipp Biermann \\ Department of Economics \\ University of Oldenburg \\ 26111 Oldenburg, Germany
}

\begin{abstract}
Previous research has found that subjective well-being (SWB) is lower for individuals classified as being in poverty. Using panel data for 39,239 individuals living in Germany from 2005-2013, we show that people's SWB is negatively correlated with the state-level poverty ratio while controlling for individual poverty status and poverty intensity. The negative relationship between aggregate poverty and SWB is more salient in the upper segments of the income distribution and is robust to controlling for the rate of unemployment and per capita GDP. The character of poverty as a public bad suggests that poverty alleviation is a matter not only of equity, but of efficiency.
\end{abstract}

Keywords: poverty; poverty ratio; subjective well-being; public bad; life satisfaction JEL classification: I31; I32; D60 


\section{Introduction}

The availability of data on subjective well-being (SWB) has greatly enhanced our ability to study the role for individual welfare of economic variables like income and unemployment. With respect to income, it is well known that richer individuals are more satisfied with their lives (Diener et al. 2010). In addition, it has recently been shown that self reported satisfaction with life is lower for those who are classified as being in poverty (Clark et al. 2015, 2016). With respect to unemployment, it is well established that not only personally being unemployed, but also the aggregate level of unemployment negatively affects SWB (Di Tella et al. 2001) or, in other words, that unemployment is not only a private bad, but a public bad.

The reasons that have been put forward for why unemployment is a public bad (Frey and Stutzer 2002) almost literally apply to poverty: People may be unhappy about poverty even if they are not poor themselves. They may feel bad about the unfortunate fate of the poor and they may worry about the possibility of becoming poor themselves in the future. They may also feel repercussions on the economy and society as a whole. They may dislike the increase in taxes likely to happen in the future. They may fear that crime and social tensions increase, and they may even see the threat of violent protests and uprisings. ${ }^{1}$

Motivated by such reasoning, this paper analyzes whether the degree of poverty prevailing in society affects SWB of people even if they are not themselves classified as being in poverty. Controlling for potentially confounding factors (in particular aggregate unemployment), we show in a fixed-effects framework that people's satisfaction with life is lower if the state-level poverty rate in Germany is higher, which suggests that poverty is a

\footnotetext{
${ }^{1}$ Frey and Stutzer (2002) write with respect to unemployment: “People may be unhappy about unemployment even if they are not themselves put out of work. They may feel bad about the unfortunate fate of those unemployed and they may worry about the possibility of becoming unemployed themselves in the future. They may also feel repercussions on the economy and society as a whole. They may dislike the increase in unemployment contributions and taxes likely to happen in the future. They may fear that crime and social tensions increase, and they may even see the threat of violent protests and uprisings."
} 
public bad. The well-being repercussions from aggregate poverty are about half as strong as the repercussions from aggregate unemployment. In addition, we find that the negative relationship between aggregate poverty and well-being is particularly salient for individuals from the upper segments of the income distribution, suggesting that poverty creates negative externalities. $^{2}$ The finding that poverty is a public bad and/or creates negative externalities indicates that poverty alleviation is a matter not only of equity, but of efficiency.

The paper is structured as follows. Section 2 discusses methodological issues. Section 3 presents the empirical results. Section 4 provides a discussion and concludes.

\section{Method}

\subsection{Poverty Measures}

The measurement of income poverty involves defining as poor all individuals whose income is below a certain threshold, referred to as the poverty line. In this paper we follow the convention applied in documents of the European Union (as do Clark et al. 2015, 2016), in which the poverty line equals 60 percent of the median equivalent income. Given an individual's status as being poor (incidence of poverty), her relative shortfall from the poverty line measures her normalized income deprivation (intensity of poverty).

Regarding the measurement of poverty at the aggregate (societal) level, a variety of measures were discussed in the literature (Foster et al. 1984, World Bank 2005). In this paper we use the poverty ratio (headcount ratio), i.e. the fraction of the population that is classified as poor, because it arguably is the poverty measure most frequently supplied by statistical offices (such as the German Federal Statistical Office) and most frequently referred to in public debates.

\footnotetext{
${ }^{2}$ Negative externalities of poverty on the non-poor are consistent with Acemoglu and Robinson (2000), who explain the emergence of redistributive programs in Western societies by a desire of the elite to prevent social unrest.
} 


\subsection{Data}

We analyze the relationship between the annual poverty ratios prevailing in the 16 states of Germany and citizens' subjective well-being, controlling for individuals' sociodemographic characteristics, the individual-level incidence and intensity of poverty, and statelevel economic conditions (unemployment rate and per capita GDP).

The data used in this analysis comes from several sources. People's subjective wellbeing (measured as reported life satisfaction), their socio-demographic characteristics, and the individual-level incidence and intensity of poverty are taken from (or computed from) the German Socio-Economic Panel (SOEP), one of the most widely used panel data sets in the subjective well-being literature. The SOEP is a panel survey based on a multi-stage random design with yearly re-interviewing (Wagner et al. 2007). Annual waves of the survey involve more than 20,000 individuals aged 16 and over in about 11,000 households. We use SOEP version 30 .

The dependent variable in our well-being regressions is the answer to the following question: "How satisfied are you at present with your life, all things considered? Please respond using the following scale, where ' 0 ' indicates not at all satisfied and ' 10 ' indicates completely satisfied.” The individual income measure we employ to create individual-level poverty measures is equivalent income, i.e. net household income divided by the square root of household size (OECD 2008). Following official EU practice, we classify individuals as poor if their equivalent income is below 60 percent of the country-level median equivalent income.

The state-level poverty ratios and the macroeconomic control variables used in this study are taken from the German Federal Statistical Office. ${ }^{3}$ Poverty ratios are based on the

\footnotetext{
${ }^{3}$ https://www.destatis. de/DE/ZahlenFakten/GesellschaftStaat/Soziales/Sozialberichterstattung/Tabellen /ArmutsgefaehrungsquoteBundeslaender.html and https://www.genesis.destatis. de/genesis/online/data; jsessionid=62C851D497B8C4AB4000449053F832 4D.tomcat_GO_1_1?operation=statistikAbruftabellen\&levelindex $=0$ \&levelid $=1477812054692$ \&index $=2$
} 
Microcensus, an official representative household survey involving about 830,000 individuals in 370,000 private households. ${ }^{4}$

Accounting for availability of comparable poverty ratios at the state level, the data set used in this paper refers to 2005-2013 and includes 172,965 observations for 39,239 individuals. The summary statistics are displayed in Table 1 . They reveal that about 12 percent of the observations refer to situations in which individuals lived in poverty (i.e., their equivalent income was below 60 percent of the median equivalent income in the respective year). The (unweighted) mean of state-year poverty ratios is somewhat higher (15 percent) because the poverty ratio tends to be high in some states with small populations. ${ }^{5}$

It should also be noted that the poverty ratio is strongly correlated with the state level unemployment rate $(r=0.80)$ and per capita GDP $(r=-0.65)$; it is therefore important to control for these macro-variables.

\subsection{Empirical Strategy}

We estimated micro-econometric life satisfaction regressions in which life satisfaction $(L S)$ of individual $i$ in state $s$ and year $t$ depends on several sets of explanatory variables:

(i) a standard set of time-variant individual-level controls (age, marital status, whether unemployed, years of education, number of children in the household, and whether the individual has moved between states in the year preceding the interview);

(ii) state-level controls (unemployment rate, per capita GDP);

(iii) being in poverty (dummy variable) and intensity of poverty (relative shortfall from the poverty line);

\footnotetext{
${ }^{4}$ We use poverty ratios from official statistics to enhance the policy credibility of our analysis. Our qualitative results are the same when we use poverty ratios computed from SOEP.

${ }^{5}$ For instance, in 2015 the poverty ratio was 24.8 percent in Bremen (population share: 0.7 percent), 22.4 percent in Berlin (population share: 3.7 percent), and 21.7 percent in Mecklenburg-Western Pomerania (population share: 2.4 percent). We use state dummies to control for state size.
} 
(iv) the state-level poverty ratio.

To account for possible endogeneity of the poverty ratio with respect to migration, we include among the time-varying individual controls a dummy variable indicating whether the individual has moved between states in the year preceding the interview. Time-invariant factors (observed and unobserved) are captured through person-fixed effects. In addition, we use state dummies and year dummies. The estimating equation can be stated as follows:

$$
\begin{aligned}
L S_{\text {ist }}= & \alpha^{\prime} \text { micro }_{\text {ist }}+\beta^{\prime} \text { macro }_{\text {st }}+\gamma^{*} \text { poor }_{\text {ist }}+\delta * \text { deprivation }_{\text {ist }}+\phi^{*} P R_{s t}+ \\
& \text { person }_{i}+\text { state }_{s}+\text { year }_{t}+\varepsilon_{i s t}
\end{aligned}
$$

where micro and macro denote the individual-level and state-level controls, respectively, poor is a dummy variable taking the value 1 if an individual is poor, deprivation is a poor individual's relative shortfall from the poverty line (set to zero for the non-poor), and $P R$ is the poverty ratio; person, state and year denote person-fixed effects and state and year dummies respectively, and $\varepsilon$ is the error term. ${ }^{6}$

As is common in the SWB literature (Ferrer-i-Carbonnel and Frijters 2004), we estimate equ. (1) using a linear fixed-effects estimator and report standard errors adjusted for clustering at the state-year level.

\section{Results}

Table 2 shows the results from versions of fixed-effect regressions corresponding to equ. (1). The first regression includes individual-level controls only (micro), whereas the following regressions also include state-level controls (macro).

\footnotetext{
${ }^{6}$ Person fixed effects control for time-invariant characteristics, both observed (sex, birth cohort, immigration status) and unobserved. State dummies capture factors such as size, population density and the degree of urbanization.
} 
In the overall sample (Regressions 1 and 2), the individual-level controls attract the expected coefficients (Clark et al. 2015): life satisfaction is u-shaped in age up until the age of 70, and it is negatively correlated with being unemployed, separated and widowed, while being positively related to being married and being divorced. ${ }^{7}$ Having moved in the year preceding the interview is significantly associated with greater life satisfaction. ${ }^{8}$ With respect to poverty, we find that both its incidence and intensity are significantly negatively correlated with life satisfaction (as was found by Clark et al. 2015, 2016).

Turning to aggregate poverty, we find that, even controlling for the incidence and intensity of poverty at the individual level, the poverty ratio is significantly negatively correlated with life satisfaction. In spite of the large correlation between the poverty ratio and the unemployment rate and per capita GDP, significance of the poverty ratio is obtained even when the latter are controlled for, but the coefficient size varies depending on whether the macro controls are included or not. It amounts to 0.0477 points when the macro controls are omitted (Regression 1) and drops to 0.0218 when the unemployment rate and per capita GDP are controlled for (Regression 2). In the latter specification, the effect of a 1-percentage point change in the poverty ratio amounts to one-half of the effect of a 1-percentage point change in the unemployment rate. The unemployment rate and per capita GDP both have significantly negative coefficients. The latter suggests that per capita GDP incorporates negative income externalities as it may act as reference income in income comparisons (Clark et al. 2008).

The following regressions split the overall sample into subsamples of poor and nonpoor individuals and subsamples of individuals whose equivalent income is below and above the annual median income. ${ }^{9}$ Considering Regressions 3 and 4, a salient result is that a significantly negative relationship between life satisfaction and the poverty ratio exists only

\footnotetext{
${ }^{7}$ As suggested by Clark et al. (2015), the latter is consistent with higher well-being as compared to a failing marriage.

${ }^{8}$ This is consistent with Faßhauer and Rehdanz (2015).

${ }^{9}$ More precisely, the subsamples refer to situations (by year) in which the respective conditions prevailed.
} 
for those who are not themselves poor, whereas the respective coefficient is non-significant and of very small magnitude for the poor. In addition, per capita GDP is significant only for the non-poor (with a negative coefficient), not for the poor. The latter suggests that for the poor it is own income, not income comparison, that matters for well-being. ${ }^{10}$ In contrast to aggregate poverty, the labor market perspectives (the unemployment rate) affect the wellbeing of the poor much stronger than that of the non-poor.

Regressions 5 and 6 strengthen the results from Regressions 3 and 4: The well-being not only of poor individuals (with income lower than 60 percent of median income), but the well-being of individuals with income lower than the median income is not significantly affected by the poverty ratio. A significantly negative relationship between life satisfaction and the poverty ratio exists only for those whose income is higher than the median income. In addition, only for the wealthier individuals does per capita GDP affect life satisfaction (weakly) significantly.

\section{Discussion and Conclusion}

This study used fixed effect regressions to investigate the relationship between statelevel poverty ratios in Germany and citizens' subjective well-being. Controlling for sociodemographic characteristics, the individual-level incidence and intensity of poverty, and potentially confounding macro-level factors, life satisfaction was found to be significantly negatively correlated with the poverty ratio, suggesting that poverty is a public bad. The wellbeing repercussions from aggregate poverty were found to be about half as strong as the repercussions from aggregate unemployment. Differentiating the overall sample by subgroups revealed that the relationship between well-being and aggregate poverty is more

\footnotetext{
${ }^{10}$ The non-significance of the poverty ratio and per capita GDP for the poor is not an artifact of the smaller size of this subsample; it survives when subsamples are of almost equal size (Regressions 5 and 6).
} 
salient for individuals whose income falls into the upper segment of the income distribution, which suggests that poverty creates negative externalities on those not poor themselves.

Possible reasons why people may be unhappy about poverty even if not poor themselves include altruism (pity), the fear of becoming poor themselves in the future, and worry about social tensions and social unrest. With respect to the latter channel, our finding that the well-being repercussions of aggregate poverty refer in particular to individuals with higher incomes is consistent with the theory of institutional reform of Acemoglu and Robinson (2000), which explains the emergence of redistributive programs in Western societies by a desire of the elite to prevent social unrest. Empirical evidence consistent with this view was presented by Yamamura (2016), who found that high-income earners' stated preference for income redistribution is related to their perceived degree of conflict between the rich and the poor.

From a policy point of view, the finding that poverty is a public bad and/or creates negative externalities suggests that poverty implies market failure. This, in turn, suggests that poverty alleviation is a matter not only of equity, but of efficiency. 


\section{References}

Acemoglu, D., Robinson, J.A. (2000), Why Did the West Extend the Franchise? Democracy, Inequality and Growth in Historical Perspective, Quarterly Journal of Economics 115, 1167-2000.

Clark, A.E., D’Ambrosio, C., Ghislandi, S. (2015), Poverty Profiles and Well-Being: Panel Evidence from Germany, Review on Economic Inequality 23, 1-22.

Clark, A.E., D’Ambrosio, C., Ghislandi, S. (2016), Adaptation to Poverty in Long-run Panel Data, Review of Economics and Statistics 98, 591-600.

Clark, A.E., Frijters, P., Shields, M. (2008), Relative Income, Happiness and Utility: An Explanation for the Easterlin Paradox and other Puzzles, Journal of Economic Literature 46, 95-144.

Di Tella, R., MacCulloch, R., Oswald, A. (2001), Preferences over Inflation and Unemployment: Evidence from Surveys of Happiness, American Economic Review 91, 335-341.

Diener, E., Ng,, W. Harter, J., Arora, R. (2010), Wealth and Happiness Across the World: Material Prosperity Predicts Life Evaluation, Whereas Psychological Prosperity Predicts Positive Feeling, Journal of Personality and Social Psychology 99, 52-61.

Faßhauer, A., Rehdanz, K. (2015), Estimating Benefits from Regional Amenities: Internal Migration and Life Satisfaction, SOEPpapers on Multidisciplinary Panel Data Research 748.

Ferrer-i-Carbonell, A., Frijters, P. (2004), How Important is Methodology for the Estimates of the Determinants of Happiness?, Economic Journal 114, 641-659.

Foster, J., Greer, J. Thorbecke, E. (1984), A Class of Decomposable Poverty Measures, Econometrica 81, 761-766.

Frey, B.S., Stutzer, A. (2002), What Can Economists Learn from Happiness Research? Journal of Economic Literature 40, 402-435.

OECD (2008), Growing Unequal? Income Distribution and Poverty in OECD Countries, Paris: Organization for Economic Cooperation and Development.

Wagner, G.G., Frick, J. R., Schupp, J. (2007), The German Socio-Economic Panel Study (SOEP): Scope, Evolution and Enhancement, Schmollers Jahrbuch / Journal of Applied Social Sciences Studies 127, 139-69.

Yamamura, E. (2016), Social Conflict and Redistributive Preferences among the Rich and the Poor: Testing the Hypothesis of Acemoglu and Robinson, Journal of Applied Economics 19, 41-64. 
Table 1: Descriptive Statistics

\begin{tabular}{|lcc|}
\hline Variable & Mean & Std. Dev. \\
\hline Life Satisfaction & 7.017293 & 1.775678 \\
Poor & 0.11818 & 0.322822 \\
Poverty Intensity & 0.0256126 & 0.0907926 \\
Poverty Ratio (\%) & 14.99433 & 3.448916 \\
Unemployed & 0.0644523 & 0.2455577 \\
Unemployment Rate (\%) & 8.814743 & 3.75851 \\
GDP p. c. (1000 Euro/year) & 30.406 & 6.466 \\
Moved & 0.1024196 & 0.3032001 \\
Age: 16-20 & 0.0233747 & 0.1510908 \\
Age: 21-30 & 0.1213193 & 0.326499 \\
Age: 31-40 & 0.1556789 & 0.3625517 \\
Age: 41-50 & 0.2071055 & 0.405233 \\
Age: $51-60$ & 0.1841876 & 0.3876382 \\
Age: $61-70$ & 0.1634146 & 0.3697446 \\
Age: 71-80 & 0.1087735 & 0.3113557 \\
Age: >80 & 0.036146 & 0.186654 \\
No. Years of Education & 12.23184 & 2.700571 \\
Single & 0.2125285 & 0.4090979 \\
Married & 0.6177088 & 0.4859486 \\
Separated & 0.0208366 & 0.1428375 \\
Divorced & 0.0794669 & 0.270467 \\
Widowed & 0.0694591 & 0.254234 \\
No. Children in HH & 0.4590524 & 0.8501726 \\
Schleswig - Holstein & 0.029451 & 0.1690676 \\
Hamburg & 0.0155754 & 0.1238261 \\
Lower Saxony & 0.0902784 & 0.286581 \\
Bremen & 0.0069783 & 0.0832444 \\
North Rhine-Westphalia & 0.2029717 & 0.4022128 \\
Hesse & 0.0693666 & 0.2540773 \\
Rhineland Palatinate & 0.0470095 & 0.2116598 \\
Baden-Wuerttemberg & 0.119105 & 0.323913 \\
Bavaria & 0.1484925 & 0.3555885 \\
Saarland & 0.0111583 & 0.1050423 \\
Berlin & 0.0472619 & 0.1894034 \\
Brandenburg & 0.2014912 \\
Mecklenburg Western Pomerania & 0.1534775 \\
Saxony & 0.2572451 \\
Saxony-Anhalt & 0.198951 \\
Thuringia & 0.2034883
\end{tabular}




\begin{tabular}{|lcc|} 
Variable & Mean & Std. Dev. \\
2005 & 0.113179 & 0.3168124 \\
2006 & 0.1207874 & 0.325881 \\
2007 & 0.1136184 & 0.3173481 \\
2008 & 0.1066748 & 0.3087002 \\
2009 & 0.1128783 & 0.3164449 \\
2010 & 0.1027491 & 0.3036318 \\
2011 & 0.1005117 & 0.3006819 \\
2012 & 0.1017778 & 0.3023568 \\
2013 & 0.1278235 & 0.3338942 \\
\hline Observations & \multicolumn{2}{c|}{172965} \\
Individuals & \multicolumn{2}{c}{39239} \\
\hline
\end{tabular}

Note: Based on SOEP v30. 
Table 2: Regression Results. Dependent Variable: 11-Point Life Satisfaction
(1)
(2)
(3)
(4)
(5)

(6)

Overall Overall Poor Not poor Inc $<$ median Inc $>$ median

\begin{tabular}{|c|c|c|c|c|c|c|}
\hline Poor (yes $=1$ ) & $\begin{array}{c}-0.120^{* * *} \\
(0.0219)\end{array}$ & $\begin{array}{c}-0.117^{* * *} \\
(0.0219)\end{array}$ & & & $\begin{array}{c}-0.114^{* * *} \\
(0.0238)\end{array}$ & \\
\hline Poverty Intensity & $\begin{array}{c}-0.327 * * * \\
(0.0817)\end{array}$ & $\begin{array}{c}-0.325^{* * *} \\
(0.0818)\end{array}$ & $\begin{array}{c}-0.490 * * * \\
(0.113)\end{array}$ & & $\begin{array}{c}-0.401 * * * \\
(0.0852)\end{array}$ & \\
\hline Poverty Ratio & $\begin{array}{c}-0.0477 * * * \\
(0.00695)\end{array}$ & $\begin{array}{c}-0.0218 * * * \\
(0.00689)\end{array}$ & $\begin{array}{l}-0.00378 \\
(0.0233)\end{array}$ & $\begin{array}{c}-0.0247 * * * \\
(0.00746)\end{array}$ & $\begin{array}{l}-0.00971 \\
(0.0117)\end{array}$ & $\begin{array}{c}-0.0224^{* *} \\
(0.0100)\end{array}$ \\
\hline Unempl. Rate & & $\begin{array}{c}-0.0436 * * * \\
(0.00617)\end{array}$ & $\begin{array}{c}-0.0862 * * * \\
(0.0224)\end{array}$ & $\begin{array}{c}-0.0319 * * * \\
(0.00664)\end{array}$ & $\begin{array}{c}-0.0532 * * * \\
(0.00981)\end{array}$ & $\begin{array}{c}-0.0315^{* * *} \\
(0.00866)\end{array}$ \\
\hline GDP p.c. & & $\begin{array}{c}-0.0195^{* *} \\
(0.00790)\end{array}$ & $\begin{array}{l}-0.0105 \\
(0.0250)\end{array}$ & $\begin{array}{c}-0.0213^{* *} \\
(0.00853)\end{array}$ & $\begin{array}{l}-0.00965 \\
(0.0125)\end{array}$ & $\begin{array}{l}-0.0177 * \\
(0.0101)\end{array}$ \\
\hline Moved & $\begin{array}{l}0.110^{* * *} \\
(0.0167)\end{array}$ & $\begin{array}{l}0.108 * * * \\
(0.0168)\end{array}$ & $\begin{array}{l}0.143^{* * *} \\
(0.0537)\end{array}$ & $\begin{array}{c}0.0988 * * * \\
(0.0167)\end{array}$ & $\begin{array}{l}0.125^{* * *} \\
(0.0326)\end{array}$ & $\begin{array}{c}0.0973 * * * \\
(0.0178)\end{array}$ \\
\hline Unemployed & $\begin{array}{c}-0.527 * * * \\
(0.0235)\end{array}$ & $\begin{array}{c}-0.522 * * * \\
(0.0236)\end{array}$ & $\begin{array}{c}-0.294 * * * \\
(0.0444)\end{array}$ & $\begin{array}{c}-0.532 * * * \\
(0.0285)\end{array}$ & $\begin{array}{c}-0.483 * * * \\
(0.0257)\end{array}$ & $\begin{array}{c}-0.436 * * * \\
(0.0421)\end{array}$ \\
\hline Age 16-20 & $\begin{array}{l}0.0954 * \\
(0.0502)\end{array}$ & $\begin{array}{l}0.0941^{*} \\
(0.0504)\end{array}$ & $\begin{array}{c}0.128 \\
(0.172)\end{array}$ & $\begin{array}{l}0.110^{* *} \\
(0.0506)\end{array}$ & $\begin{array}{l}0.168^{* *} \\
(0.0834)\end{array}$ & $\begin{array}{c}0.0494 \\
(0.0646)\end{array}$ \\
\hline Age $21-30$ & $\begin{array}{c}0.0295 \\
(0.0352)\end{array}$ & $\begin{array}{c}0.0259 \\
(0.0352)\end{array}$ & $\begin{array}{c}0.101 \\
(0.126)\end{array}$ & $\begin{array}{l}0.00645 \\
(0.0367)\end{array}$ & $\begin{array}{c}0.114 * \\
(0.0593)\end{array}$ & $\begin{array}{c}-0.0143 \\
(0.0448)\end{array}$ \\
\hline Age $31-40$ & $\begin{array}{l}-0.0150 \\
(0.0196)\end{array}$ & $\begin{array}{l}-0.0198 \\
(0.0195)\end{array}$ & $\begin{array}{c}-0.112 \\
(0.0842)\end{array}$ & $\begin{array}{r}-0.00976 \\
(0.0188)\end{array}$ & $\begin{array}{l}-0.0360 \\
(0.0337)\end{array}$ & $\begin{array}{l}-0.0140 \\
(0.0220)\end{array}$ \\
\hline Age 51-60 & $\begin{array}{c}0.0450 * * \\
(0.0183)\end{array}$ & $\begin{array}{c}0.0433^{* *} \\
(0.0183)\end{array}$ & $\begin{array}{c}0.103 \\
(0.0798)\end{array}$ & $\begin{array}{c}0.0313 * \\
(0.0183)\end{array}$ & $\begin{array}{c}0.0998 * * * \\
(0.0376)\end{array}$ & $\begin{array}{c}0.0261 \\
(0.0213)\end{array}$ \\
\hline Age 61-70 & $\begin{array}{c}0.153^{* * *} \\
(0.0285)\end{array}$ & $\begin{array}{c}0.151^{* * *} \\
(0.0286)\end{array}$ & $\begin{array}{l}0.0715 \\
(0.124)\end{array}$ & $\begin{array}{c}0.145^{* * *} \\
(0.0289)\end{array}$ & $\begin{array}{c}0.244^{* * *} \\
(0.0597)\end{array}$ & $\begin{array}{c}0.132 * * * \\
(0.0345)\end{array}$ \\
\hline Age $71-80$ & $\begin{array}{c}0.0599 \\
(0.0371)\end{array}$ & $\begin{array}{c}0.0547 \\
(0.0371)\end{array}$ & $\begin{array}{l}-0.130 \\
(0.172)\end{array}$ & $\begin{array}{c}0.0676^{*} \\
(0.0363)\end{array}$ & $\begin{array}{c}0.111 \\
(0.0716)\end{array}$ & $\begin{array}{l}0.0851 * \\
(0.0478)\end{array}$ \\
\hline Age $>80$ & $\begin{array}{l}-0.123 * * \\
(0.0542)\end{array}$ & $\begin{array}{l}-0.128^{* *} \\
(0.0543)\end{array}$ & $\begin{array}{c}-0.498^{* *} \\
(0.212)\end{array}$ & $\begin{array}{l}-0.0711 \\
(0.0578)\end{array}$ & $\begin{array}{c}-0.126 \\
(0.0967)\end{array}$ & $\begin{array}{l}-0.0600 \\
(0.0678)\end{array}$ \\
\hline Education & $\begin{array}{l}-0.0177 * * \\
(0.00763)\end{array}$ & $\begin{array}{c}-0.0179 * * \\
(0.00767)\end{array}$ & $\begin{array}{l}-0.0609 * \\
(0.0365)\end{array}$ & $\begin{array}{l}-0.00568 \\
(0.00809)\end{array}$ & $\begin{array}{l}-0.0159 \\
(0.0160)\end{array}$ & $\begin{array}{l}-0.0211^{* *} \\
(0.00962)\end{array}$ \\
\hline Married & $\begin{array}{c}0.139 * * * \\
(0.0295)\end{array}$ & $\begin{array}{c}0.142 * * * \\
(0.0295)\end{array}$ & $\begin{array}{l}-0.0798 \\
(0.129)\end{array}$ & $\begin{array}{c}0.164 * * * \\
(0.0300)\end{array}$ & $\begin{array}{c}0.238 * * * \\
(0.0568)\end{array}$ & $\begin{array}{l}0.112 * * * \\
(0.0364)\end{array}$ \\
\hline Separated & $\begin{array}{c}-0.174 * * * \\
(0.0585)\end{array}$ & $\begin{array}{c}-0.169 * * * \\
(0.0586)\end{array}$ & $\begin{array}{l}0.0673 \\
(0.194)\end{array}$ & $\begin{array}{c}-0.215^{* * *} \\
(0.0602)\end{array}$ & $\begin{array}{c}0.0879 \\
(0.0957)\end{array}$ & $\begin{array}{c}-0.324 * * * \\
(0.0721)\end{array}$ \\
\hline Divorced & $\begin{array}{c}0.217^{* * *} \\
(0.0552)\end{array}$ & $\begin{array}{c}0.219 * * * \\
(0.0554)\end{array}$ & $\begin{array}{c}0.489 * * \\
(0.207)\end{array}$ & $\begin{array}{c}0.208 * * * \\
(0.0516)\end{array}$ & $\begin{array}{c}0.372 * * * \\
(0.0987)\end{array}$ & $\begin{array}{c}0.230^{* * *} \\
(0.0633)\end{array}$ \\
\hline Widowed & $\begin{array}{c}-0.210^{* * *} \\
(0.0548)\end{array}$ & $\begin{array}{c}-0.206^{* * *} \\
(0.0549)\end{array}$ & $\begin{array}{c}-0.441^{* *} \\
(0.217)\end{array}$ & $\begin{array}{c}-0.207 * * * \\
(0.0552)\end{array}$ & $\begin{array}{c}-0.0832 \\
(0.0937)\end{array}$ & $\begin{array}{c}-0.271^{* * *} \\
(0.0822)\end{array}$ \\
\hline No. Of Children & $\begin{array}{c}0.0194 * \\
(0.0114)\end{array}$ & $\begin{array}{c}0.0175 \\
(0.0114) \\
\end{array}$ & $\begin{array}{l}0.103 * * \\
(0.0463)\end{array}$ & $\begin{array}{r}0.00576 \\
(0.0121) \\
\end{array}$ & $\begin{array}{c}0.0264 \\
(0.0183) \\
\end{array}$ & $\begin{array}{c}0.0161 \\
(0.0141)\end{array}$ \\
\hline Year dummies & $\begin{array}{l}\text { Yes } \\
\text { Yes }\end{array}$ & $\begin{array}{l}\text { yes } \\
\text { ves }\end{array}$ & $\begin{array}{l}\text { yes } \\
\text { ves }\end{array}$ & yes & $\begin{array}{l}\text { yes } \\
\text { ves }\end{array}$ & yes \\
\hline $\begin{array}{l}\text { State dummies } \\
\mathrm{N}\end{array}$ & $\frac{\text { Yes }}{172965}$ & $\frac{\text { yes }}{172965}$ & $\frac{\text { yes }}{20441}$ & $\begin{array}{c}\text { yes } \\
152524\end{array}$ & $\frac{\text { yes }}{77664}$ & $\frac{\text { yes }}{94102}$ \\
\hline R-sq & 0.014 & 0.015 & 0.019 & 0.012 & 0.017 & 0.011 \\
\hline
\end{tabular}


Note: Fixed-effects regressions with standard errors adjusted for state-year clustering. ${ }^{*} \mathrm{p}<0.10$, ${ }^{* *} \mathrm{p}<0.05$, ${ }^{* * *} \mathrm{p}<0.01$. Reference categories: Age $40-50$, Single. Observation numbers differ between Regressions 5 and 6 because subsamples are separated by yearly median income and observation numbers differ by year. Based on SOEP v30. 